\title{
河川・海岸におけるストレス軽減効果と 音・熱環境の影響の検討 \\ STUDY ON HEALING EFFECT FROM RIVER AND COAST AND ITS RELATION TO SOUND AND THERMAL ENVIRONMENTS
}

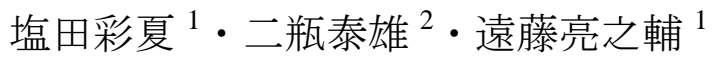 \\ Ayaka SHIODA, Yasuo NIHEI and Ryonosuke ENDO \\ 1 学生員 学 (工) 東京理科大学大学院 理工学研究科土木工学専攻修士課程 \\ （干278-8510 千葉県野田市山崎 2641） \\ 2正会員 博 (工) 東京理科大学准教授 理工学部土木工学科（同上）
}

\begin{abstract}
Although previous studies pointed healing effects from waterfront, quantitative evaluations and factor of healing effects were still unknown. To evaluate quantitatively healing effects from river and coast and its associated factors, in this study, we measured simultaneously psychological stress and sound and thermal environments at six sites in which the measuring points were selected near waterfront and urban area in its neighborhood. The measured results indicated that 1) the measured values of salivary amylase activity, one of useful stress markers, in several waterfronts were appreciably lower than those in urban area, and 2) the healing effects in waterfronts were closely related to sound and thermal environments.
\end{abstract}

Key Words: salivary amylase activity, waterfront, healing effect, sound environment, thermal environment

\section{1. 序論}

河川や海岸における水辺整備は，防災（治水）・水利 用 (利水) - 環境面を考慮して公共事業として行われて いるが，公共事業費は年々減少しており，今後の水辺整 備は先細りする可能性が高く「水辺」の新たな価值を創 造する必要がある。この水辺の新たな価值として「スト レス軽減効果 (癒し効果)」が注目される ${ }^{1)}$. 福祉・医 療分野においても水辺利用が試みられる等の日常的な河 川空間の利用が提案・実施されている $\left.{ }^{2)}, 3\right)$ 。この水辺の 癒し効果を科学的に証明し, その要因を把握することは, 「癒し」を考慮した水辺整備を推進する上で必要である. 水辺の癒し効果やそれと類似した「快適性」に関する 研究はこれまで多く行われている.研究初期の段階では, 水辺の快適性に関するアンケート調査や官能試験を中心 として行われ，それらに対する水辺の環境要素である音 4) 〜7), 熱 8)，9)，景観 (視覚）10）との関連性が調べられ ている. その後, 心理状況の把握にアンケート調査だけ でなく，脳波や血圧，脈拍などの物理項目の計測も行わ れ, 水辺の癒し効果が検討されている ${ }^{11)}$. しかしながら, ストレス評価を精緻に把握するには上記の物理項目だけ では不十分であり, 血液や唾液, 尿等の化学項目の計測 の必要性が指摘されている ${ }^{12)}$.
近年, 化学項目のストレスマーカーとして唾液中の $\alpha$ アミラーゼ活性（唾液アミラーゼ活性）が注目され，簡 便に計測し得る機器も市販化されている ${ }^{12)}$ 。また，唾液 アミラーゼ活性を指標とした水辺の癒し効果の検証も行 われている ${ }^{13)}$ 14) 。しかしながら，水辺の癒し効果に関 する定量評価やその要因の検討は不十分であり, より客 観的な視点から水辺のストレス軽減効果を議論していく ためには，ストレス状況やそれに影響を与える環境要因 に関する多くの実測データを収集していく必要がある.

それに対して，著者らは，「唾液アミラーゼ活性」の 簡便な計測機器を用いて，河川や湖沼の癒し効果を検討 するとともに，それが親水性により変化することを明ら かにした (本宮・二瓶 ${ }^{15}$ ), 以下, 前報と呼ぶ) 。本研究 では，これを受けて，多くの水辺（河川や海岸）におい て，唾液アミラーゼ活性による心理ストレス計測と水辺 環境の中で主な要素である音・熱環境を同時計測し，水 辺のストレス軽減効果を定量的に検討するとともに，そ れらに対する音環境・熱環境の影響を調べることを試み た. ここでは, 前報の結果に加え, 河川（多摩川）と海 岸 (千葉県・稲毛海岸) の追加調査を行っており, 水辺 のストレス軽減効果そのものやそれに対する音・熱環境 の関係性を把握する. 


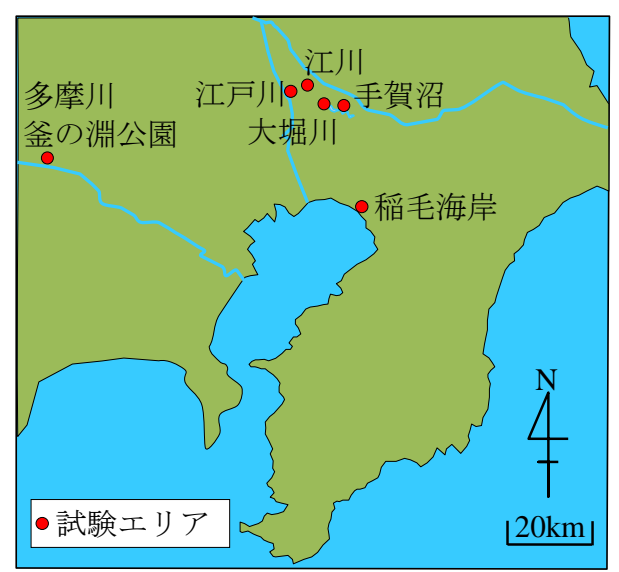

図-1＼cjkstart各試験エリアの位置

表-1 本試験の実施状況

\begin{tabular}{|c|c|c|c|c|c|c|}
\hline & 見測日 & 場所 & & 場所, 人 & 数 & 音熱 \\
\hline & $8 / 27$ & 江戸川 & $\begin{array}{c}\text { 水辺 } \\
4\end{array}$ & & $\begin{array}{c}\text { 市街地 } \\
4\end{array}$ & -10 \\
\hline & & 江川 & $\begin{array}{c}\text { 水辺 } \\
2 \\
\end{array}$ & & $\begin{array}{c}\text { 市街地 } \\
2\end{array}$ & -0 \\
\hline 2 & $9 / 6$ & 大堀川 & $\begin{array}{c}\text { 水辺 } \\
2\end{array}$ & & $\begin{array}{c}\text { 市街地 } \\
2\end{array}$ & -0 \\
\hline $\begin{array}{l}0 \\
1\end{array}$ & & 手賀沼 & $\begin{array}{c}\text { 水辺 } \\
2\end{array}$ & & $\begin{array}{c}\text { 市街地 } \\
2\end{array}$ & -0 \\
\hline 0 & $11 / 11$ & 手賀沼 & $\begin{array}{c}\text { 水辺 } \\
2\end{array}$ & & $\begin{array}{c}\text { 市街地 } \\
2\end{array}$ & 00 \\
\hline & $11 / 20$ & 江戸川 & $\begin{array}{c}\text { 水辺 } \\
2 \\
\end{array}$ & & $\begin{array}{c}\text { 市街地 } \\
2 \\
\end{array}$ & 00 \\
\hline & $111 / 22$ & 大堀川 & $\begin{array}{c}\text { 水辺 } \\
2\end{array}$ & & $\begin{array}{c}\text { 市街地 } \\
2\end{array}$ & 00 \\
\hline & 9/9 & 江戸川 & $\begin{array}{c}\text { 水辺 } \\
5 \\
\end{array}$ & & $\begin{array}{c}\text { 市街地, 堤内地 } \\
5 \\
\end{array}$ & (1) \\
\hline 2 & $9 / 16$ & \begin{tabular}{|l|} 
稲毛 \\
海岸 \\
\end{tabular} & $\begin{array}{c}\text { 水辺 } \\
7\end{array}$ & $\begin{array}{c}\text { 防風林前 } \\
4\end{array}$ & $\begin{array}{c}\text { 市街地, 公園 } \\
7\end{array}$ & (0) \\
\hline 1 & $11 / 9$ & 多摩川 & $\begin{array}{c}\text { 水辺(瀬) } \\
9\end{array}$ & $\begin{array}{c}\text { 水辺(淵) } \\
6\end{array}$ & $\begin{array}{c}\text { 市街地 } \\
3\end{array}$ & (-) 0 \\
\hline & $12 / 7$ & \begin{tabular}{|l|} 
稲毛 \\
海岸 \\
\end{tabular} & \begin{tabular}{|c} 
防風林前 \\
4 \\
\end{tabular} & & $\begin{array}{c}\text { 公園 } \\
4 \\
\end{array}$ & (0) \\
\hline 2 & $7 / 27$ & 多摩川 & 水際 $(2 \mathrm{~m})$ & 水際 $(14 \mathrm{~m})$ & 水際 $(26 m)$ & (a) 0 \\
\hline 0 & & & 4 & 3 & 3 & \\
\hline 1 & $9 / 14$ & \begin{tabular}{|l|} 
稲毛 \\
海岸 \\
\end{tabular} & $\begin{array}{c}\text { 水辺 } \\
2\end{array}$ & $\begin{array}{c}\text { 防風林前 } \\
5\end{array}$ & $\begin{array}{c}\text { 市街地 } \\
3\end{array}$ & (0) \\
\hline
\end{tabular}

\section{2. 研究方法}

\section{（1）観測サイト}

試験サイトは，図-1に示すように，河川（江戸川（堤 内幅 $60 \mathrm{~m}$ ）, 江川（水面幅 $12 \mathrm{~m}$ ）, 大堀川（水面幅 $8 \mathrm{~m}$ ), 多摩川（水面幅 7m）），湖沼（手賀沼）と海岸（稲毛海 岸)である. 観測を行った日付・場所と観測内容の概略 を表-1に示す. 2010年度に行った観測では, 「水辺」と 水辺から離れた「周辺域」を測定点として設け,「周辺 域」としては，道路脇等の市街地を選定した．2011，12 年度では, 江戸川では 2010年度と同じであるが, 新規の 稲毛海岸と多摩川では, 図-2のように, 水辺近傍でもい
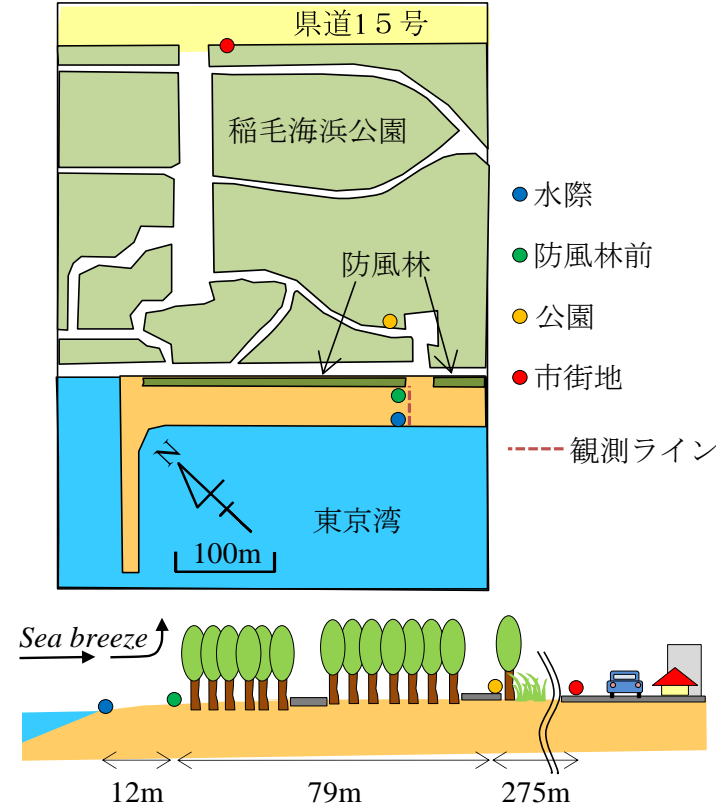

(a) 稲毛海岸

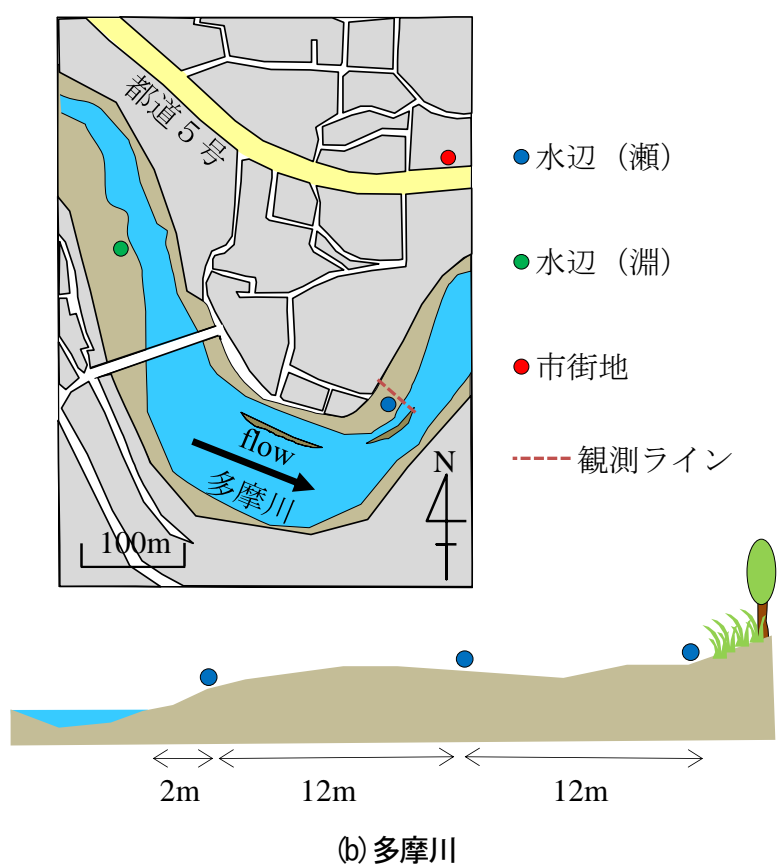

図-2 観測地点の配置 (詳細図, 観測ライン縱断図)

くつか観測点を設けている．まず，稲毛海岸は，浜幅の 狭い砂浜海岸であり，背後には防風林や公園が存在して おり，狭い空間内でも音・熱環境の変化が予想される. そのため，海岸空間として「水辺」と同じ浜辺内の最も 水際から離れた地点（「防風林前」と称す）の2点を設 け，周辺域として「市街地」と「公園」を設けている. 多摩川・青梅では瀬と淵が存在しており，音環境のコン トラストが存在していることから，水辺として「瀬」と 「淵」が設定され，さらに，「瀬」付近の水際からの横 断距離が異なる 3 地点の同時計測も行われている.

\section{（2）観測方法}


上記サイトにて，心理ストレスと音・熱環境を同時に 現場計測する. 心理ストレスについては, 前報と同じく, 対象試験地点に行く前に, 人工的なストレス負荷を与え， 試験地点に移動した後のストレス減少度合いを地点間で 比べる. 具体的には，ストレス負荷時（開始 $0 \sim 20$ 分） ではヘッドフォンを装着し大音量で不快な音楽（ヘヴィ メタル）を聴く等の負荷を与え, その後, 試験地点に移 動し, 安静時 (開始 25〜45 分) では散歩や座るなどリラ ックスした状態でいる. その間に，唾液アミラーゼ活性 を専用測器（唾液アミラーゼモニター，ニプロ侏製）に より測定する. 唾液アミラーゼ活性に含まれる個人差を 無くすために, 比較指標として「無次元唾液アミラーゼ 活性 $A^{\prime} 」 （=$ 安静時の值（ $t=35,45$ 分）/ストレス負 荷時の最大值（ $t=10 \sim 25$ 分））を採用する. 試験対象者 は, 東京理科大学学生の 20 歳代の男女であり, 各測定点 には最低 2 名以上割当てられ, 各観測の人数は表-1に示 すとおりである. なお，夏季では，試験中に喉が渇き， 唾液が出ないケースが見られたため，2012年度の調査で は, 被験者は唾液アミラーゼ活性計測の 5 分以上前に毎 回水道水でうがいをした。

次に，音環境計測では，基本観測としてマルチ環境測 定器（LM-8102，佐藤商事(侏製）を用いて各地点の音圧 を計測した. また, 詳細観測として, PCMレコーダー(リ ニア PCM レコーダーLS-11，OLYMPUS(侏製）を用いて, サンプリング周波数 $44.1 \mathrm{kHz}$ で録音し, 音圧・音質を計 測・分析した. 両者ともに, 各地点において最低 1 分間 以上にわたり，底面から約 $1 \mathrm{~m}$ の環境音を収録した。 ま た, 水際からの距離に対寸る音環境の変化を把握するた めに, 稲毛海岸では水際から防風林前まで（2012/9/14 実 施），多摩川では水際から 26m地点までを（2012Л127実 施），それぞれ2〜3m間隔で録音した。

熱環境計測では，基本観測として，上記のマルチ環境 測定器により風速, 温湿度を各地点約 1 分間計測した. また，詳細観測としては，風向風速（03001-L），純放射 量（Q7.1-L20，以上，太陽計器侏製）日射量（MS-601, 英弘精機㑣製），温湿度（HOBOProV2 U23-001, Onset社 製），地表面温度（サーモ・ピッパー，佐藤商事(株製) を各地点 5〜10 分間測定した. これらの結果を用いて, 人体に与える熱フラックス指標である仮想熱負荷量 ${ }^{16}$ を求める.

唾液アミラーゼ活性計測と合わせて, アンケート調查 を行っている. 内容は, 現在の自分のストレス状態を 5 段階で評価するとともに, 音・熱環境の心地良さについ ても5 段階評価で行った. なお, アンケート項目のうち, ストレス状態は全試験で行っているが, 音・熱環境の心 地良さに関しては, 2011 年度以降の調査のみで行った.

\section{（3）データ解析方法}

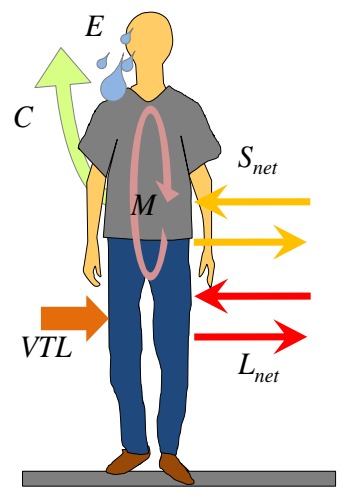

(a) 人体の熱収支

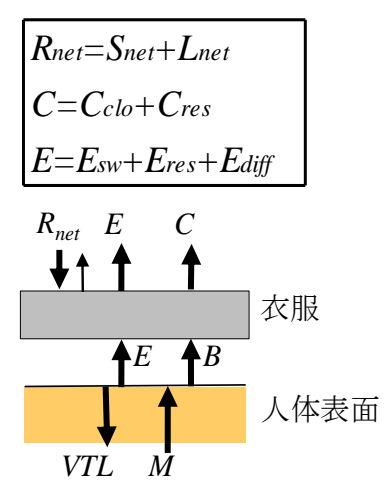

(b) 熱収支概念図
図-3人体熱収支解析の概念図

\section{a）音のスペクトル解析}

水辺のストレス軽減効果に対する音環境の影響を把握 するために，音の快・不快に用いられる「1/fゆらぎ ${ }^{17} 」$ に代表される音のスペクトル分布を算出する. 音のスペ クトルデータを用いた「音の快・不快」に関寸る検討事 例はいくつか存在するが，ここでは野村・石井 ${ }^{18)}$ に倣い 高周波数帯 $(3 \mathrm{k} \sim 10 \mathrm{kHz})$ における音のパワースペクトル の傾きに着目する，スペクトル解析を行う際には，各地 点において記録された 1 分間の音データを用いる.

\section{b）人体への熱ストレス評価}

人体一の熱負荷指標としては, 神田ら ${ }^{10}$ が提唱する仮 想熱負荷量 VTL（Virtual Thermal Load）を採用する. 人体 における熱収支解析には, 図-3(a)に示寸ように, 代謝量 $M$, 正味放射量 $R_{n e t}$ 衣服から大気一の顕熱 $C$ と潜熱 $E$ を考慮すると，以下のように与えられる.

$$
V T L=M+R_{n e t}-C-E
$$

ここでは，着衣状態の人体熱収支として，人体一衣服間 と衣服一大気間の熱収支を次式のように与える.

$$
\begin{array}{ll}
\text { 【人体一衣服間】 } & V T L=M-B-E \\
\text { 【衣服一大気間】 } & R_{n e t}=C-B
\end{array}
$$

ここで人体から衣服への顕熱フラックスを $B$ とし,また, 潜熱 $C$ は連続条件により境界面間で変化しないものとし, 式(2)より式(1)が得られる. 各フラックスの与え方として は，図-3(b)に示寸ように，正味放射量 $R_{\text {net }}$ には水平方向 の短波・長波放射の和，顕熱 $C$ と潜熱 $E$ には，衣服か ら大気一の熱輸送 $C_{c o} \cdot E_{s w}$, 呼吸成分 $C_{r e s} \cdot E_{r e s}$, 皮膚 からの不感蒸泄熱 $E_{\text {diff }}$ の和とする. 詳細観測データがあ る場合には，上記の方法で実施し，各項の算出方法の詳 細は, 神田ら ${ }^{16)}$ を参照されたい. また, 基本観測結果の みの場合には，前報と同じやり方と寸る.

\section{（4）音環境のみの快適度に関する室内試験}

音環境のみによる心理ストレスを調べるべく音源を知 らない被験者 8 人 (東京理科大学学生) に 4 種類の現地 
環境音 (多摩川の瀬と淵, 市街地, 稲毛海岸の水際) を 1 分間聞かせ，音の心地良さに関するアンケート調査を 行う.ここでの音量は河川の瀬付近（58dB）を基準とし て与えている.

\section{3. 結果と考察}

\section{（1）水辺と周辺域におけるストレス軽減効果の比較}

数多くのデータの蓄積がなされた唾液アミラーゼ活性 の計測データを用いて，水辺におけるストレス軽減効果 を抽出する．まず，表-1に示すように，延べ13回，6つ の観測サイトで行われた無次元唾液アミラーゼ活性 $\overline{A^{\prime}}$ データを用いて，水辺と周辺域における無次元唾液アミ ラーゼ活性 $\overline{A^{\prime}}$ を比較したものを図-4に示寸.ここでは, 各データの平均值と標準偏差を示寸と共に, データ数 $n$ も表示している. また，同図(a)〜(c)には，全データ， 水域每（河川，海岸），季節毎（夏季，秋・冬季）に分 けた形で表示している. なお，ここでは，水辺と周辺域 において同時計測されたもののみを対象とする.

まず，全データ（水辺 $n=42$, 周辺域 $n=38 ）$ を見ると, 無次元唾液アミラーゼ活性 $\overline{A^{\prime}}$ の平均值は, 水辺と周辺 域でそれぞれ 60.3\%，81.8\%である．標準偏差を考慮して も, 水辺における無次元唾液アミラーゼ活性 $\overline{A^{\prime}}$ は周辺 域と比べて小さいことが分かる. これらの水辺と周辺域 における唾液アミラーゼ活性の計測結果の差が有意であ るかを確認するために， t 検定を行う。ここでは，帰無 仮説として「水辺と周辺域のストレス軽減効果に有意差 はない」，対立仮説として「水辺と周辺域のストレス軽 減効果に有意差がある」という二つの仮説を立て $P$ 值 が 0.05 を下回れば帰無仮説を棄却することができる.こ のケースの $P$ 值を求めた結果, $P=0.00200$ となり， 0.05 よ りも十分小さく, 水辺では周辺域よりもストレス軽減効 果は高いことが実証された。

次に，水域毎の比較として（同図（b)），河川と海岸 において別々に水辺と周辺域の無次元唾液アミラーゼ活 性 $\overline{A^{\prime}}$ を比べる. まず, 河川（水辺 $n=21$, 周辺域 $n=20$ ) では, $\overline{A^{\prime}}$ の平均值は, 水辺・周辺域において各々 $53.3 \%$, $77.8 \%$ でり , 全データの場合よりも両者間の差は大きい. この差の有意性を確認するために，同様に $\mathrm{t}$ 検定を行っ たところ, $P=0.0118<0.05$ となり, 河川でも周辺域と比 べて水辺のストレス軽減効果が有意であることが示され た. 一方, 海岸（水辺 $n=17$, 周辺域 $n=14$ ）では, $\overline{A^{\prime}}$ の 平均值では，水辺 $(69.6 \%)$ が周辺域 $(89.4 \%)$ を明確に 下回るものの, 同じ $\mathrm{t}$ 検定により得られた $P$ 值は, $P=$ 0.0715 となり 0.05 を上回ったことから, その差の有意性 は確認できなかった，海岸調査における周辺域には, 緑 地が豊富な「公園」が含まれる $(n=14$ 中， 8 個）。緑地 は水辺とは異なる瘉し効果が報告されており ${ }^{19)}$, 公園は,

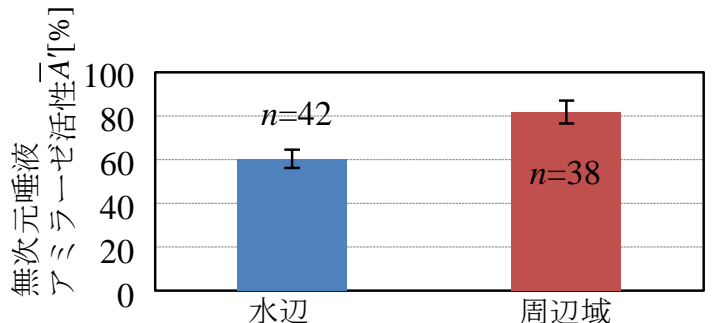

(a) 全データ
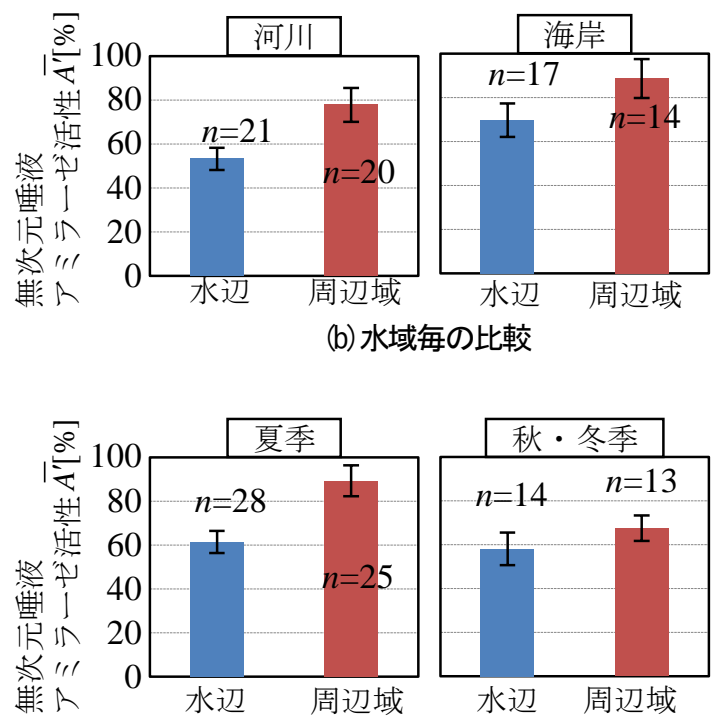

(c) 季節毎の比較

\section{図-4 水辺と周辺域における無次元唾液アミラ一ゼ活性 $\overrightarrow{A^{\prime}}$} の平均値の比較

本来分けて扱うべきであったが，海岸調査の市街地デー タが不十分であったので，上記の結果となった. 今後, 多くのデータを蓄積し, 海岸のストレス軽減効果の有意 性を検証する必要がある。

さらに，季節別の結果を見てみると（同図（c）），夏 季 $\left(8,9\right.$ 月) では, $\overline{A^{\prime}}$ の平均值は, 水辺 $(n=28)$ と周 辺域 $(n=25)$ でそれぞれ 61.5\% と $87.0 \%$ となり， $\mathrm{t}$ 検定の $P$ 值も $P=0.00636<0.05$ となり, 水辺のストレス軽減効果 の有意性が確認された．また，秋・冬季（11，12月）に は水辺 $(n=14)$ と周辺域 $(n=13)$ での $\overline{A^{\prime}}$ の平均值は, 各々 $58.1 \%$ と $65.7 \%$ となり，水辺の值が下回るものの，上記の 結果の中では, 水辺と周辺域の差は最も小さい。この結 果, $\mathrm{t}$ 検定でも $P=0.416$ となり有意性は確認されていな い. この周辺域にも「公園」データが含まれ，今後，観 測データを増やして検討する必要がある.

このように, 水辺のストレス軽減効果は明確に現れ， 全般的に周辺域との有意差も検証されており, 特に, 「河 川」と「夏季」にその傾向が顕著であることが示された.

\section{（2）ストレス軽減効果の要因}

\section{a) 熱環境}

上述した水辺のストレス軽減効果の要因を調べるため, 水辺と周辺域の熱環境の違いについて仮想熱負荷量 $V T L$ 


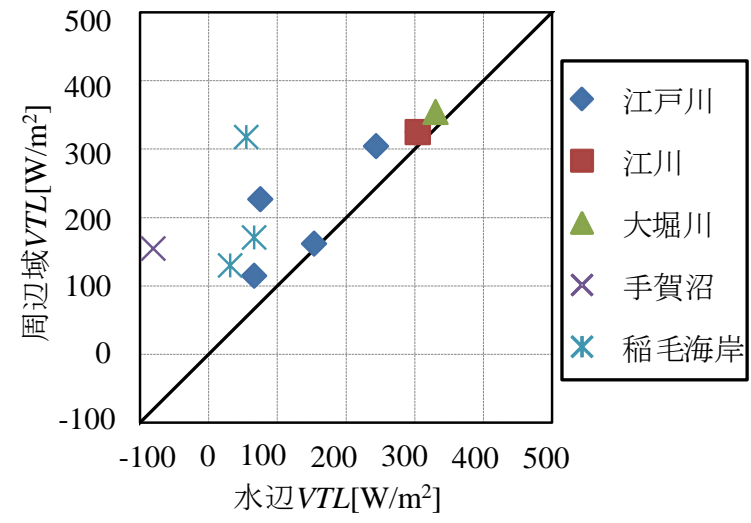

図-5 水辺と周辺域における仮想熱負荷量 $V T L$ の相関図

を用いて調べる. 図-5は，水辺と周辺域におけるVTLの 相関図を比較したものである. ここでは, 水辺と周辺域 にて熱的なコントラストが形成され易い夏季のデータを 示す．また，観測サイト毎にマークを分けて表示してい る.

これより, 水辺よりも周辺域のVTLが全般的に大きく, 特に，稲毛海岸や手賀沼において，その傾向が顕著であ る. 夏季海岸の日中では, 海風により海面上の冷気が砂 浜や背後地に移流され，それによる冷却効果が生じる9． 同様な状況は，湖沼でも生じており，手賀沼では，観測 時には湖内からの発散風が $5 \mathrm{~m} / \mathrm{s}$ 以上となっていた。 これ らの結果，水辺におけるVTLが周辺地よりも十分小さく なっているものと考えられる. 同様な傾向は，大河川で ある江戸川ではある程度見られているが，川幅が狭い都 市河川である大堀川や江川では，水辺と周辺域の熱環境 の差が小さいため, VTLの差も小さい. 以上より, 水辺 の泠源効果を発揮できる水域サイズ（海岸・湖沼）もし くは風の道となり得る大河川では, 熱環境緩和効果が有 意であり，夏季における水辺ストレス軽減効果に大いに 寄与しているものと考えられる. また，その他の季節で は，夏季ほどの熱的な違いが水辺と周辺域で見られない ことから，熱環境緩和効果が水辺のストレス軽減効果に 効果的に影響するのは夏季のみであるものと考えられる. (b) 音環境

もう一つのストレス軽減効果の要因と考えられる音環 境の効果を検討するために, 音のスペクトル分布に着目 寸る. 図-6は，本観測より得られた代表的な水辺と周辺 域における音のパワースペクトルを示寸。ここでは, 水 辺として, 多摩川の瀬と淵 (2011/11/9), 稲毛海岸 (水 際，2011/12Л）とし，周辺域として市街地 (2011/11/9) の 結果が表示されている。これより，音の快・不快に関係 する高周波数帯（3k～10kHz）では，音のパワースペクト ルはほぼ直線的に右肩下がりとなる.この高周波数帯(図 中点線の部分）のデータに対して対数関数の近似式 $(y=a \log x+b)$ を当てはめた. この傾き $a$ の大きさとして

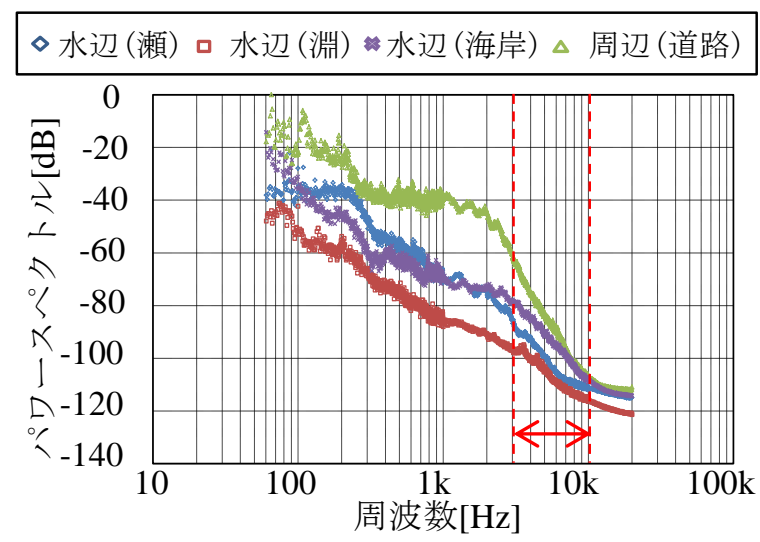

図-6 水辺と周辺域のパワースペクトル

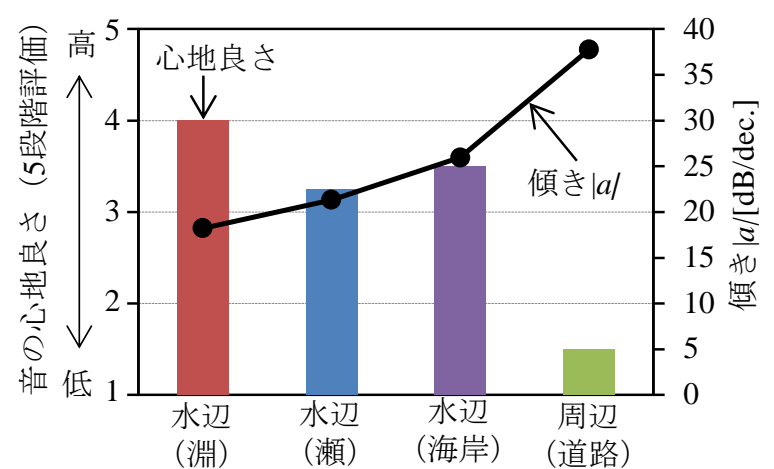

図-7 音のパワースペクトルにおける高周波数との傾き $|a|$ と 音の心地よさの比較（室内アンケート結果）

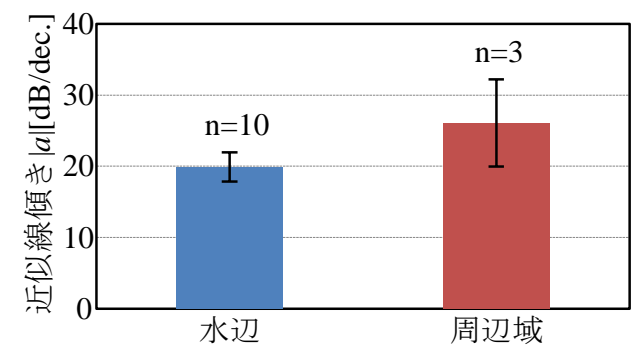

図-8＼cjkstart水辺と周辺域における傾き $|a|$ の比較

は, 市街地＞水辺（海岸）>水辺（瀬）＞水辺（淵）の 順に急となっている. そこで，上記の4箇所の環境音に 関する心地良さの室内アンケートを取り，その結果と上 記の傾き $|a|$ を比べたものを図-7に示寸.これより，傾き $|a|$ が大きくなると, 音の心地良さは概称悪くなっている. この傾向は野村・石井 ${ }^{18)}$ の結果と一致しており, 水辺の 方が心地良い音環境が形成されていることが分かる.

より多くのデータに対して，高周波数領域における音 のパワースペクトルに近似直線を適用し，その傾き $|a|$ を 水辺と周辺域において求めた結果を図-8 に示寸. このよ うに, 水辺の傾き $|a|$ は周辺域よりも小さく, 多くの水辺 において，心地良い環境音が形成されていることが示さ れると共に，このような音環境が水辺のストレス軽減効 果の一因となっていることが示唆された.

（3）水辺空間内のストレス · 音 · 熱環境の空間変化 


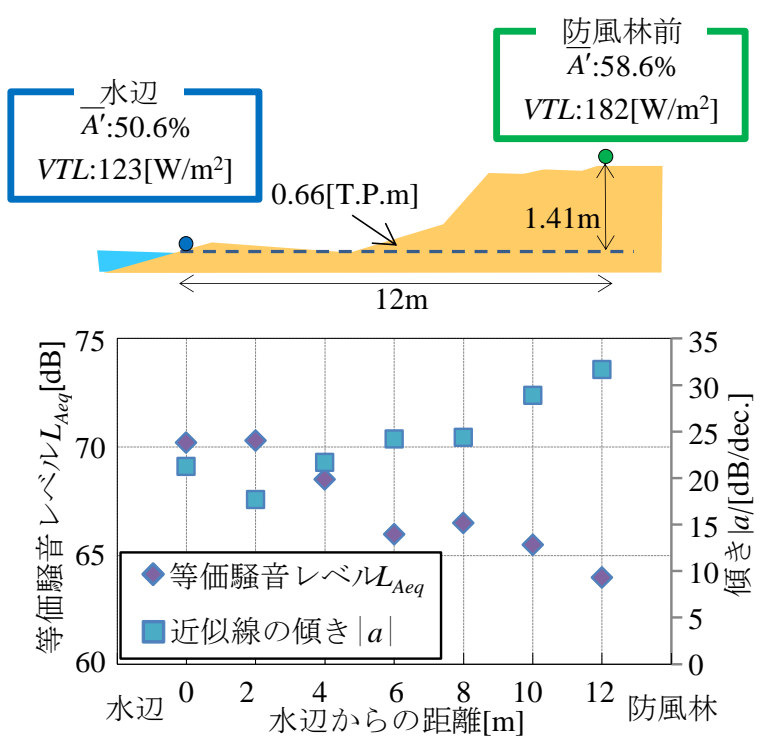

図-9 水辺空間内におけるストレス · 熱 - 音の空間分布 (稲毛海岸, 2012/9/14)

水辺空間内におけるストレス・音・熱環境の変化とし て，夏季・稲毛海岸（2012/9/14 14時）を例に，水辺（汀 線より $2 \mathrm{~m}$ ) と防風林前（同 $14 \mathrm{~m}$ ) の無次元唾液アミラー ゼ活性 $\overline{A^{\prime}}, V T L$ 及び等価騒音レベル $L_{\text {Aeq }}{ }^{20}$ ) (騒音レベル のエネルギーに着目した時間平均值）と音のスペクトル の傾き $|a|$ の空間分布を図-9に示寸.これより, 水辺では, 防風林前と比べて $\overline{A^{\prime}}$ は小さく, 熱の $V T L$ や音の傾き $|a|$ も小さく，ストレス軽減効果に音・熱環境の影響が見て 取れる.また, 音環境データより, 汀線から離れると, 音圧レベルが減少すると共に, スペクトルの傾き $|a|$ が増 加しており, 既存の研究成果と類似している ${ }^{4)}$ 〜0).この ように, 海岸の砂浜は海風の加熱効果 (夏季) ${ }^{9)}$ や波の 音の減衰・吸音効果を有し，水際で形成された熱・音環 境を変化させていることが分かる.

\section{4. 結論}

本研究で得られた主な結論は次の通りである.

1 ) 水辺には周辺域よりも高いストレス軽減効果があり， その一部は統計的に有意差があることが検証された.

2）ストレス軽減効果の要因である音・熱環境共に，水 辺の方が周辺域よりも快適性が高い.

3）稲毛海岸を例に, 水辺空間内において, 水辺とそこ から離れた地点で観測を行ったところ，ストレス・ 音・熱環境の空間変化が見られ，海岸砂浜の機能が これらの空間変化に関係していることが示唆された.

なお，本研究では様々な水辺間のストレス軽減効果を比 較しておらず，水辺環境の違いによるストレス軽減効果 の違いは不明であるので，今後の課題とする.
謝辞 : 現地観測実施に対して，東京理科大学理工学部土 木工学科水理研究室学生諸氏には多大なる御助力を頂い た.ここに記して謝意を表す.

\section{参考文献}

1) 吉川勝秀 : 人・川・大地と環境 自然共生型流域圈・都市 に向けて，技報堂出版，pp.69-182，2004.

2) 伊藤一正，福成孝三，塚本昇，吉川勝秀 : 川での福祉・医 療と教育効果の増進に関寸る研究, 河川技術論文集, Vol.16, pp.459-464, 2010.

3) 小松寛治, 大須賀滝子, 石川みゆき, 木内利恵, 斎藤孝喜, 工藤浩二，高橋義輝，岡部真理，佐藤義朝，高橋修三，小 松かずゆ:川の持つ癒し効果について, 河川, No.704, pp.5-11 2005.

4) 灘岡和夫，徳見敏夫 : 海岸の音環境に関寸る基礎的研究, 海岸工学論文集, Vol.35, pp.757-761, 1988.

5) 灘岡和夫，玉嶋克彦：海岸環境要素としての波の音の特性 について, 海岸工学論文集, Vol.36, pp.869-873， 1989.

6) 村上仁士，伊藤禎彦，細井由彦，小川慶樹，小藪剛史 : 砕 波による波の音の発生特性に関寸る考察, 海岸工学論文集, Vol.40, pp.1116-1120, 1993.

7) 土屋十国, 中村良夫 : 親水水路にみる流水形態と音環境の 特性, 造園杂倠誌, Vol.56, No.5, pp.229-234, 1993.

8) 神田学, 木内豪, 小林裕明 : 新しい屋外用温熱感指標によ る河川の熱環境評価 一多摩川河川旉における観測を例に 一, 水工学論文集, Vol.40, pp.237-242, 1996.

9) 灘岡和夫，内山雄介，山下哲弘 : 海岸空間アメニティ構成 要素としての微気象および温熱環境の解析，土木学会論文 集, No.533／II-34, pp.193-204，1996.

10) 木内㶳，栗城稔，小林裕明 : 複合環境下における河川空間 と周辺市街地の快適性評価，環境システム研究，Vol.23， pp.561-566, 1995

11）宮本高行，重枝実，杉山滋，大島章嘉，冨樫聖代子 : 海辺 利用によるリラックス効果測定調查, J.Int. Soc. Life Info. Sci, Vol.19, No.1, pp.38-46, 2001.

12) 山口昌樹 : 唾夜マーカーでストレスを測る，日本薬理学䧱 誌, Vol.129, No.2, pp.80-84, 2007.

13）畠堀誉子，菅和利，丸井英一: 唾液アミラーゼを用いた河 川空間の癒し効果の定量評価，河川技術論文集，Vol.11， pp.577-582, 2005.

14）菅和利, 長島拓也, 清水佳之 : ストレス指標を用いた水辺 環境評価手法の開発, 河川技術論文集, Vol.17, pp.377-382, 2011.

15）本宮和英，二瓶泰雄 : 唾液アミラーゼ活性を指標とした河 川・湖沼のストレス軽減効果把握の試み, 河川技術論文集, Vol.17, pp383-388, 2011.

16) 神田学, 柳本記一, 宇梶正明 : 新しい屋外用温熱感指標の 提案，土木学会論文集，No.545/II-36, pp.1-10， 1996.

17）武者利光：ゆらぎの世界，講談社，pp.141-156, 1980.

18）野村俊昭，石井六哉：スペクトル解析による快音・不快音 の特徵抽出, 電子情報通信学会, デジタル信号処理, Vol.95, No.68, pp.39-46, 1995.

19）岩崎宽, 山本聡, 石井麻有子, 渡辺幹夫 : 都市公園内の芝 生地およびラベンダー畑が保有する生理・心理的効果に関 する研究, 日本緑化工学会誌, Vol.33, No.1, pp.116-121, 2007.

20) 橘秀樹, 矢野博夫 : 環境騒音・建築音響の測定, コロナ社, pp.64-65, 2004.

(2012. 9.30 受付） 